Ethiopian Journal of Environmental Studies \& Management 10(4): 427 - 442, 2017.

ISSN:1998-0507

doi: https://dx.doi.org/10.4314/ejesm.v10i4.1

Submitted: October 04, 2016

Accepted: May 24, 2017

\title{
OIL SPILL ASSESSMENT IN IJEODODO AREA OF LAGOS STATE, NIGERIA USING GEOSPATIAL TECHNIQUES
}

*MAKINDE, E.0. AND TOLOGBONSE, A.S.

Department of Surveying and Geoinformatics, Faculty of Engineering, University of

Lagos, Akoka, Lagos State, Nigeria

\begin{abstract}
Oil spill negatively impacts man and his environment, thereby affecting human lives, animals and plants. The occurrence of it has increased in Nigeria specifically, Lagos State, bringing grave environmental and economic effects. Thus, this paper assessed the impact and vulnerability of oil spill posed in the study area and the possibility of a management strategy, from satellite imageries (Landsat ETM ${ }^{+} 7$ (2011) and Landsat ETM 8 (2014 and 2015)) to water and soil surveys using Geospatial techniques. The result showed in total, that there was a rise in built-up areas of the land cover classification of about $58.9 \%$ and a decline of $29.1 \%$ in vegetation for 2011, 2014 and 2015. Heavy metal such as Iron (Fe), Lead $(\mathrm{Pb})$, Zinc $(\mathrm{Zn})$ and Phosphate $\left(\mathrm{PO}_{4}\right)$ tested in water and soil were apparent, with phosphate $\left(\mathrm{PO}_{4}\right)$ having the highest concentration of $289.370 \mathrm{mg} / \mathrm{l}$ in water and 3.750 $\mathrm{mg} /$ in soil. This paper concludes that oil spill affected the study area and thus there is a need for an effective and efficient response management system in Nigeria.
\end{abstract}

Keywords: Oil Spills, Land Cover Change, Heavy Metals, Emergency Response Model

\section{Introduction}

An oil spill is the discharge of refined petroleum into the environment due to human activity, and is a form of pollution (Osuji, 2004). Oil spills have posed a great threat to the environment of the oil producing areas, which if not successfully crisscross can lead to the total destruction of ecosystems (FME, 2006). Oil that is spilled in and not recovered will have an impact on the local environment, spreading over a wide area and affecting both terrestrial and marine resources. Improper clean-up actions can add up to worse situation never bargained for. The development of the region has led to the degradation of some sites reducing their value and use. For example, loss of viable agricultural land, translating into shortfalls of livelihood for farmers including the loss of ancestral homes, familiar surroundings, religious and other cultural artefacts which are the psychological and social glitches associated with displacements (NDES, 1997).

Sabotage as when known is as result of pipeline vandalization. Sabotage represents different acts that interfere with the production and distribution of petroleum products. Sabotage is currently the leading cause of oil spillage in

*Corresponding Author: Makinde, E.O.

Email: eomakinde@unilag.edu.ng 
Nigeria. According to Johnson (2004) the pipeline explosion has killed hundreds of thieves and onlookers. Ojediran and Ndibe (2005) reported that an average of 35,000 barrels of crude oil is siphoned per day threaten human lives and the environment. Besides the loss of lives and property through pipeline fire, the overspill from impacted sites frequently degrade the quality of the fresh water sources which serves the domestic water needs of most community dealers in Nigeria.

However, it is generally agreed that oil spill is dangerous to the functioning environment which by nature is very difficult to clean up if polluted by oil. It is clear that as long as petroleum resource is being explored, exploited and oil pipeline facilities are exposed, spills will still take place. Minimizing them and their effects need to be traversed mainly as the people most affected by the spill are those in the host communities where oil pipelines cut across, the exploration and exploitation of crude oil is being carried out specifically. To curtail the risky of oil spill, there is need for an allinclusive emergency GIS based plan for oil spill management (Udoh et al., 2011).

In this paper, it was found out that oil spill effects, ranges from impacts on water and land to that of soil, resulting in hardship, neglect by other communities, pollution of the environment making what's important to every living thing harmful, which is water; finally, health and life in general. It significantly testifies to the severity of oil spill incident on the communities in Lagos. Also in a larger realm, oil spill brings along with it ecological damages (interms of market and non-market losses) leading to commercial fishing, lost revenue from recreational site closures, loss of oil and industrial or drinking water consumption closure; including impacts on recreational, wetlands, natural habitat, wildlife and natural resources (USEPA, 2009).

\section{Study Area}

The study area is in the geographic coordinate of $6^{\circ} 30^{\prime}-6^{\circ} 28^{\prime} \mathrm{N}$ and $3^{\circ} 14^{\prime}$ - $3^{\circ} 15^{\prime} \mathrm{E}$; within 191,056 path and roll and it falls in Time zone of WAT $(\mathrm{UTC}+1)$, and Area code(s) of 01 . It covers an expanse of about 10Sq.m within the Local Government. Ijeododo is a rural community which is located in Ojo Local Government Area (L.G.A), Oto-Aori and Iba Local Community Development Area (LCDA), Lagos State, Nigeria. Ojo Local Government Area in Lagos State is surrounded by different towns like Ijegun and Abule-ado. The total population of Ojo L.G.A is 609,173 (2006 Census, from the National Population Commission, Lagos. The study area is shown in Fig. 1. 

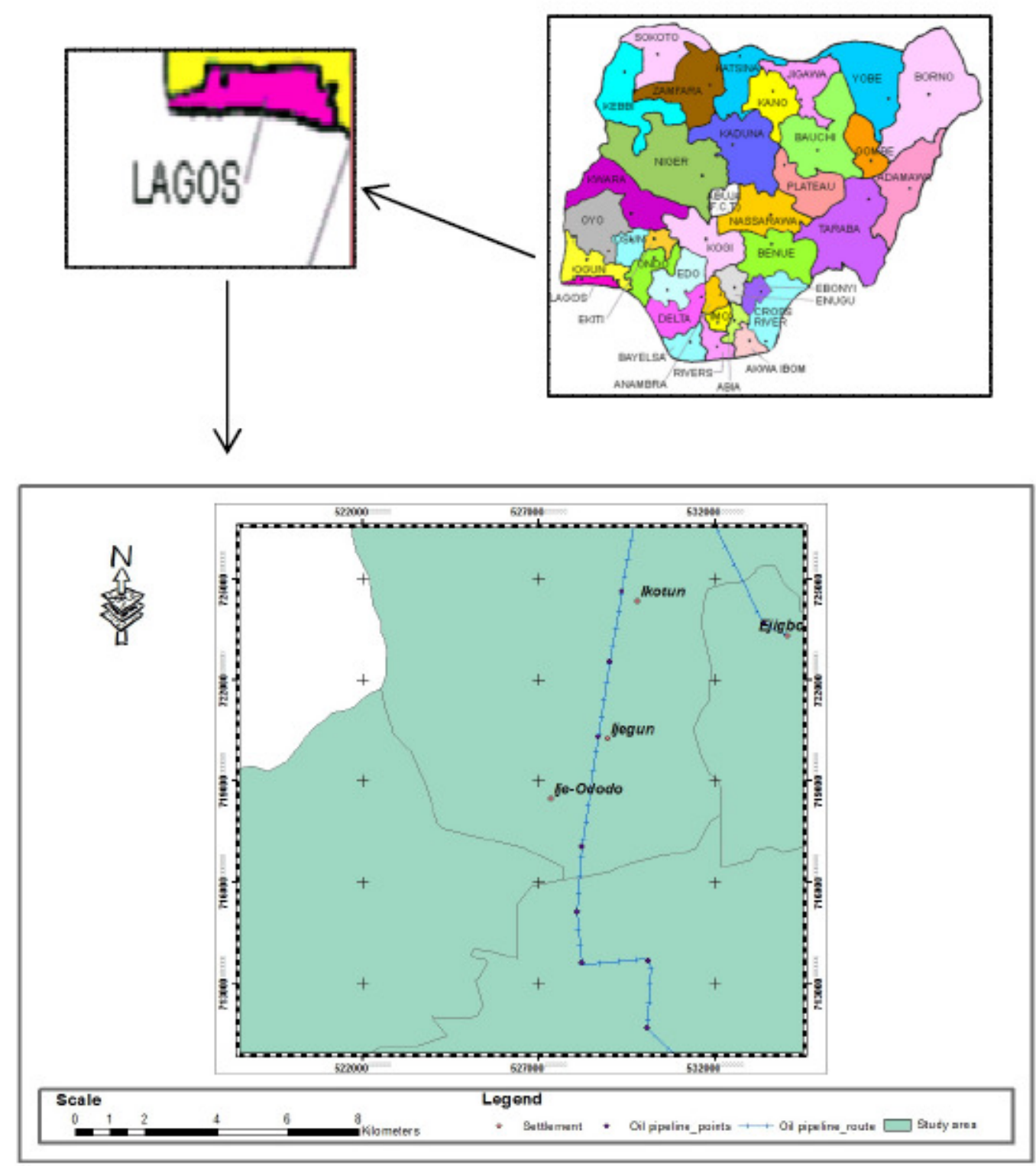

Fig. 1: The Study Area

\section{Materials and Methods}

Two techniques were considered to define the views of oil spill effect on the affected areas and are detailed in this stage. First, the use of geospatial techniques which involved the analysis of satellite imageries, assessing the vulnerability of oil spill amidst the effect it poses and develop a strategy to which emergency response plan can be undertaken. Secondly, water and soil assessment were done to analyse the effect of oil spill with respect to heavy metal concentration as against the acceptable Standard.

Geo-spatial information analysis was undertaken to locate affected settlements, assess the effect, and to evaluate the vulnerability along the oil pipeline. A multi-datasets including Landsat 
Enhanced Thematic Mapper Plus $\left(\mathrm{ETM}^{+}\right)$ for 2011, 2014, 2015 satellite imageries of the study area were used. For the classification, a modification scheme of Hardy and Anderson (1973), Anderson et al. (1976) and (2001) were used. Four land cover classes of Built up area, Vegetation, Water body and Bare ground were used. ERDAS IMAGINE (9.2) software was used to implement maximum likelihood classification algorithm. The parametric rule of maximum likelihood was adopted. After which features were exported as shapefiles into ArcMap. This process was repeated for the three year Landsat imageries. The rate of change for the land cover was also calculated.

Subsequently, multiple ring buffering was used to form equidistance around the object of interest. The Euclidian distance buffer in ArcGIS whose input geometry is buffered by calculating offsets using a two-dimensional distance formula was used. The buffer zones were built around the oil pipelines at distances of $0.5 \mathrm{~km}, 1$ $\mathrm{km}, 1.5 \mathrm{~km}$, and $2 \mathrm{~km}$. Four vulnerability zones (very high, high, moderate, and marginal) were assigned using a single output map algebra tool to produce a vulnerability model. Also, an emergency response model was derived using the ArcGIS Cost distance tool which calculates the least accumulative cost distance for each cell to the nearest source over a cost surface. Also, the road network was used as the input source data while a land cover (2015) of the area was used as the input cost distance surface data, and both input data were in raster format for this operation.

For the water and soil assessment, a Garmin handheld GPS (GPSMAP 64) was used in randomly selecting impacted points where both water and soil samples were collected. Samples were collected within a radius of $2 \mathrm{~m}$. This was to ascertain the impact of oil spill in the community by testing for the presence of heavy metals (such as Iron (Fe), Lead $(\mathrm{Pb})$, Zinc ( $\mathrm{Zn})$, Phosphate (PO4)) and its level of concentration (Lenntech, 2004; Sekabira et al., 2010) within the study area.

Four water samples were randomly selected from different dug wells in Ijeododo community (impacted area) and one from a borehole in Ikotun community which served as the Control. A precleaned 0.75 litre plastic bottle, rinsed with the intended water sample was used to collect the samples. A $100 \mathrm{ml}$ of thoroughly well mixed water sample was transferred into a beaker and $5 \mathrm{ml}$ concentrated nitric acid was added. The beaker was placed on a hot plate and evaporated to dryness. The beaker was then cooled and another $5 \mathrm{ml}$ concentrated nitric acid was added. Heating was continued until a lightcoloured residue was observed. Then $1 \mathrm{ml}$ concentrated nitric acid was added and the beaker was warmed slightly to dissolve the residue. The walls of the beaker were then washed with distilled water. The volume was adjusted to $50 \mathrm{ml}$. Then, iron, zinc and lead were determined in the digested samples. A 25 $\mathrm{ml}$ water sample was measured into a beaker $\left(100 \mathrm{~cm}^{3}\right)$ a phosphate powder pillow was added into it and held for minutes. After three (3) minutes the concentration of phosphate were read directly on (spectronic $20^{\mathrm{D}+}$ ) at $890 \mathrm{~nm}$.

Meanwhile, four soil samples were randomly collected and a Control sample also. The soil samples were collected at near-surface with tools such as hand 
trowel, and collecting material. Surface debris were carefully removed and the samples taken at depth of zero to $15 \mathrm{~cm}$ (Babatunde and Tosin, 2012). A hand Trowel was used to cut a block of the desired soil and the sample appropriately collected and secure tightly in the dark leather bag. Soil sample was transferred into a $50 \mathrm{ml}$ beaker and $20 \mathrm{ml}$ of concentrated nitric acid was added. The mix was allowed to stand for $2 \mathrm{~h}$ prior to heating on a hot plate. Heating was carried out at $150{ }^{\circ} \mathrm{C}$ for $6 \mathrm{~h}$ until the organic soil material is completely dissolved resulting in an almost clear solution and steam. The solution was allowed to cool at room temperature, filtered into a $25 \mathrm{ml}$ volume flask and made up to volume with distilled water. This solution was aspirated into a Varian AAS 200 spectrophotometer to determine the metals. A four lamp turret Varian 200 flame AA spectrometer was optimized for the determination of Lead, Iron, Zinc and Phosphate as tested for. The metals were measured in milligram per litter $(\mathrm{mg} / \mathrm{l})$ and milligram per kilogram $(\mathrm{mg} / \mathrm{kg}) ; \quad$ water and soil sample respectively.

\section{Results \\ Land Cover Distribution, Change and Maps}

The results of the area occupied by each land cover type are shown in Table 1. It was observed that built-up area covered $43.5 \%$ in 2011 and had increase to $69.1 \%$ by 2015 . Also, vegetation covered $32.0 \%$ in 2011, while it reduced to $26.1 \%$ in 2015.

Furthermore, the rate of change that occurred within three years was explicitly outlined showing the rise and decline nature of each class (Table 2). For instants, between 2014 and 2015, there was a decline in vegetation of about 10.1 $\%, 47.2 \%$ for bare ground and $5.8 \%$ for water body; while within the same year interval there was a rise of about $7.9 \%$ for built up area. The land cover maps of 2011, 2014, and 2015 are shown in Fig.2, Fig. 3, and Fig. 4 respectively. It presents the analyses of the land cover distribution, the affected settlements, the road network and the oil pipeline route.

Table 1: Land Cover Distribution

\begin{tabular}{lllllllll}
\hline \multicolumn{8}{c}{ Classification Area (Sq. Km) and Percentage (\%) } \\
\hline \multirow{2}{*}{ Land Cover } & $2011($ Area $)$ & $2014($ Area $)$ & $2015($ Area $)$ & Total & \\
\cline { 2 - 9 } & $($ Sq.Km) & $(\%)$ & $($ Sq.Km) & $(\%)$ & $($ Sq.Km) & $(\%)$ & $($ Sq.Km $)$ & $(\%)$ \\
\hline Built Up & 110.4 & 43.5 & 162.4 & 64.0 & 175.2 & 69.1 & 448.0 & 58.9 \\
Vegetation & 81.2 & 32.0 & 73.6 & 29.1 & 66.2 & 26.1 & 221.1 & 29.1 \\
Bare Ground & 38.8 & 15.3 & 10.6 & 4.2 & 5.6 & 2.2 & 55.0 & 7.2 \\
Water Body & 23.1 & 9.1 & 6.8 & 2.7 & 6.4 & 2.5 & 36.3 & 4.8 \\
Total & 253.5 & 100 & 253.5 & 100 & 253.5 & 100.0 & 760.4 & 100 \\
\hline
\end{tabular}


Table 2: Percentage Rate of Change

\begin{tabular}{lllllll}
\hline \multicolumn{7}{c}{ Rate of Change } \\
\hline \multirow{2}{*}{ Land Cover } & $2011 \&$ & 2014 & \multicolumn{2}{c}{$2011 \& 2015$} & $2014 \& 2015$ \\
\cline { 2 - 7 } & $(\%)$ & Report & $(\%)$ & Report & $(\%)$ & Report \\
\hline Built Up & 47.1 & Rise & 58.8 & Rise & 7.9 & Rise \\
Vegetation & -9.3 & Decline & -18.5 & Decline & -10.1 & Decline \\
Bare Ground & -72.6 & Decline & -85.5 & Decline & -47.2 & Decline \\
Water Body & -70.4 & Decline & -72.1 & Decline & -5.8 & Decline \\
\hline
\end{tabular}
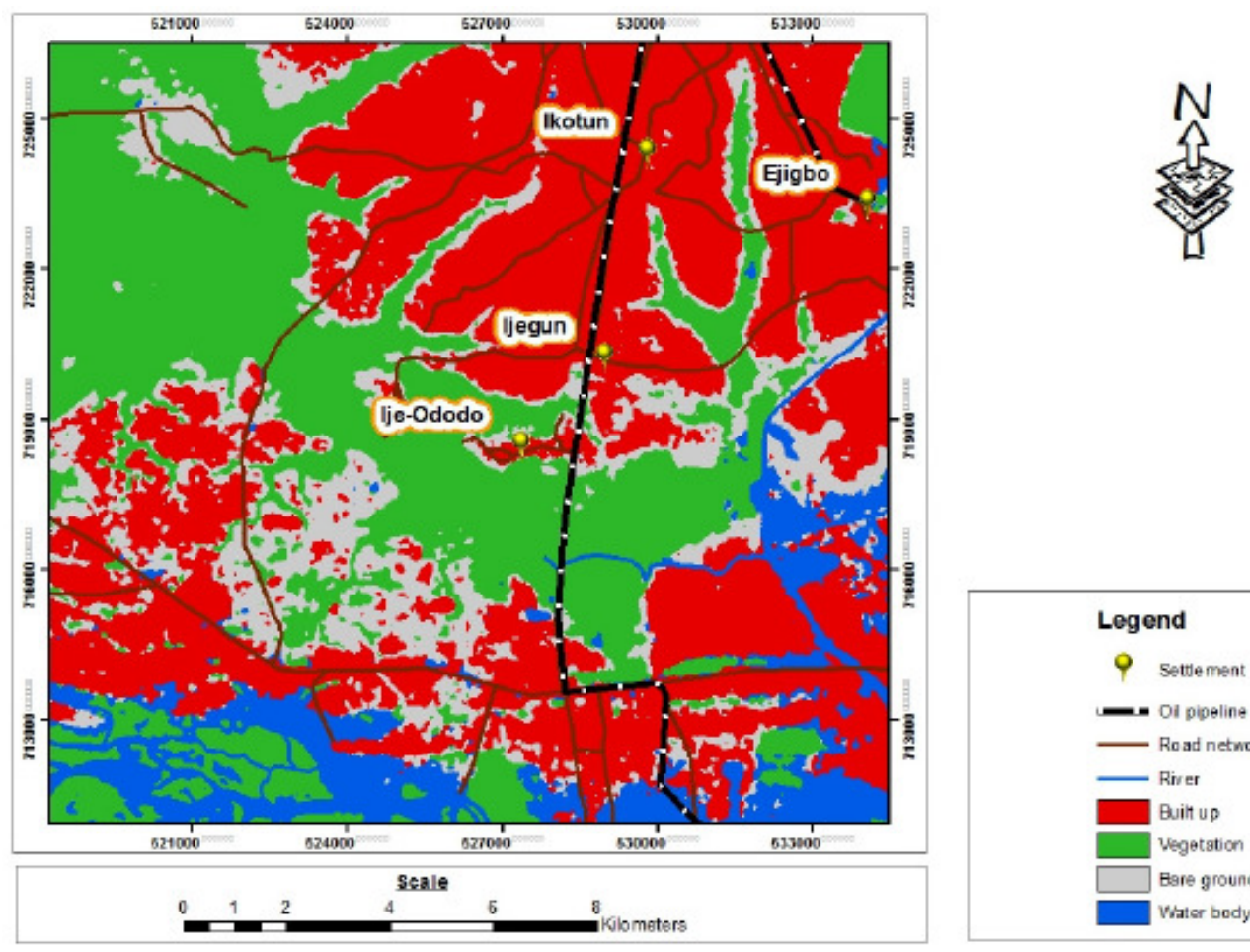

Fig. 2: Land Cover Map of 2011 
Ethiopian Journal of Environmental Studies and Management Vol. 10 no.4 2017
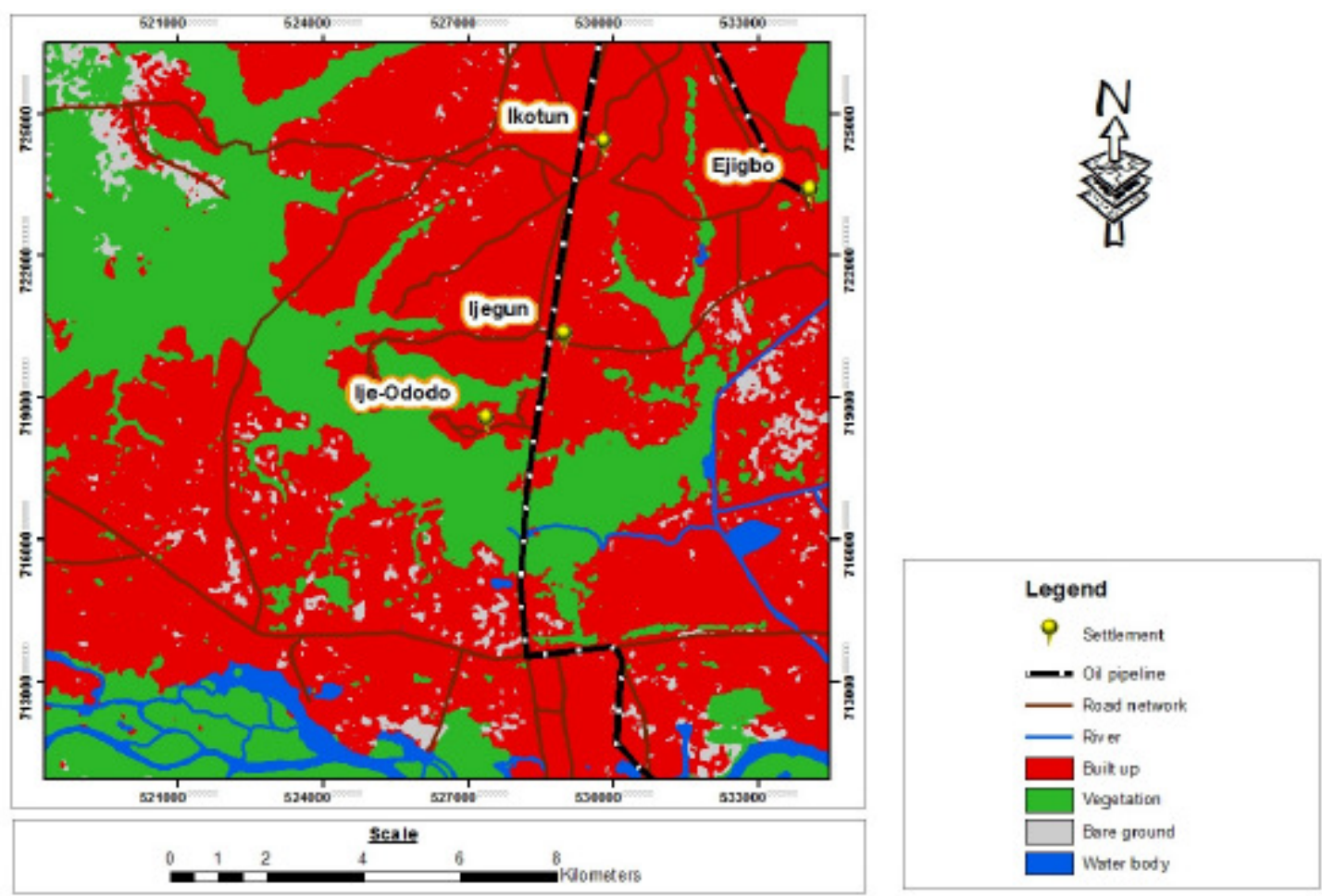

Fig. 3: Land Cover Map of 2014
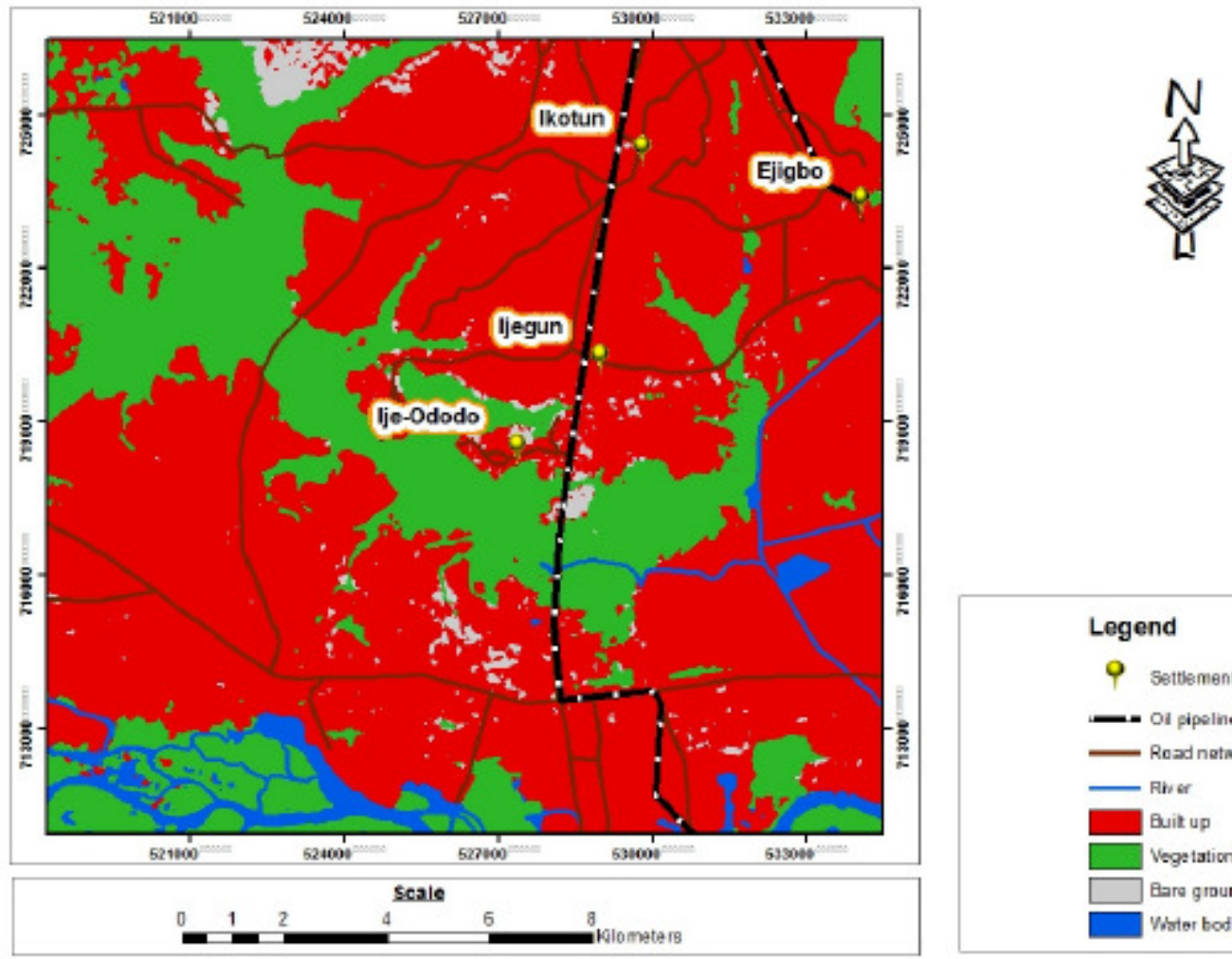

Fig. 4: Land Cover Map of 2015 


\section{Buffer, Vulnerability and Response Analysis}

Buffer analysis was done to assess the hazard areas along the oil pipeline as it affects the settlement and the land cover.
Distances of $0.5 \mathrm{~km}, 1 \mathrm{~km}, 1.5 \mathrm{~km}$ and 2 $\mathrm{km}$ were buffered around the input feature (oil pipeline) using a multiple ring buffer (analysis) tool of ArcMap (Fig. 5).

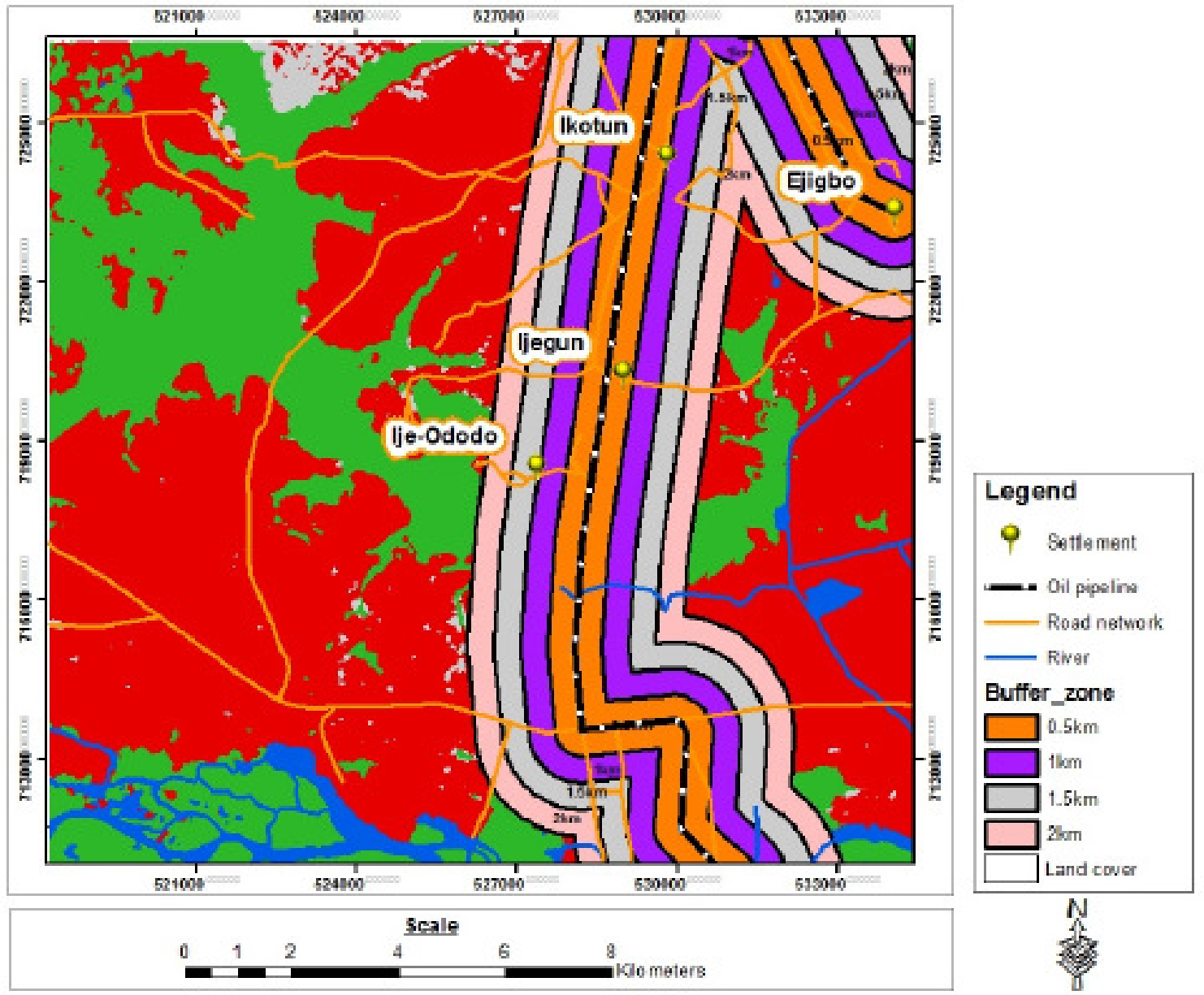

Fig. 5: Shows Overlay of Four Buffer Zones around the Oil Pipeline

Vulnerability analysis was done to assess the degree to which man and his environment are exposed to loss, injury or damages caused by the impact of oil spill in the study area. A vulnerability model was then developed from two vulnerability surface layers (land cover surface, and accessibility surface) combined together using single output algebra of ArcMap. The output was then re-classed and zoned into four vulnerability zones (very high, high, moderate, marginal) (Table 3), with respect to the nature of the terrain (Fig. 6 ). These four vulnerability zones were assessed as regards the area (Sq.km) and percentage $(\%)$ within the vulnerability zones (Fig. 7). 
Table 3: Vulnerability Zone Assessment

\begin{tabular}{llll}
\hline S/N & Zones & Sq.km & $\%$ \\
\hline 1 & Very High & 90.1 & 39.1 \\
2 & High & 60.2 & 26.1 \\
3 & Moderate & 44.5 & 19.3 \\
4 & Marginal & 35.8 & 15.5 \\
& Total & 230.7 & 100.0 \\
\hline
\end{tabular}

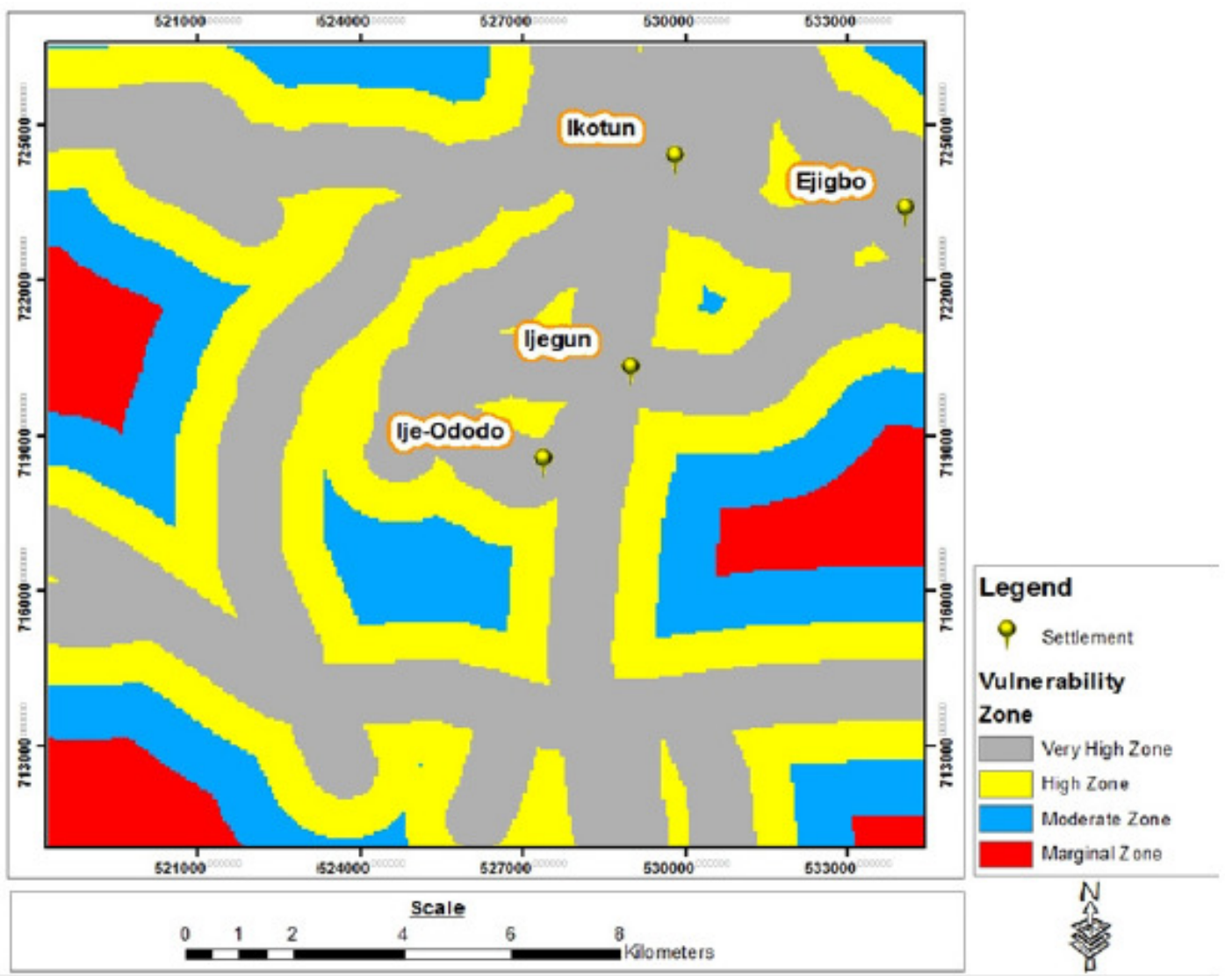

Fig. 6: Vulnerability Model Map showing Vulnerability Zone 


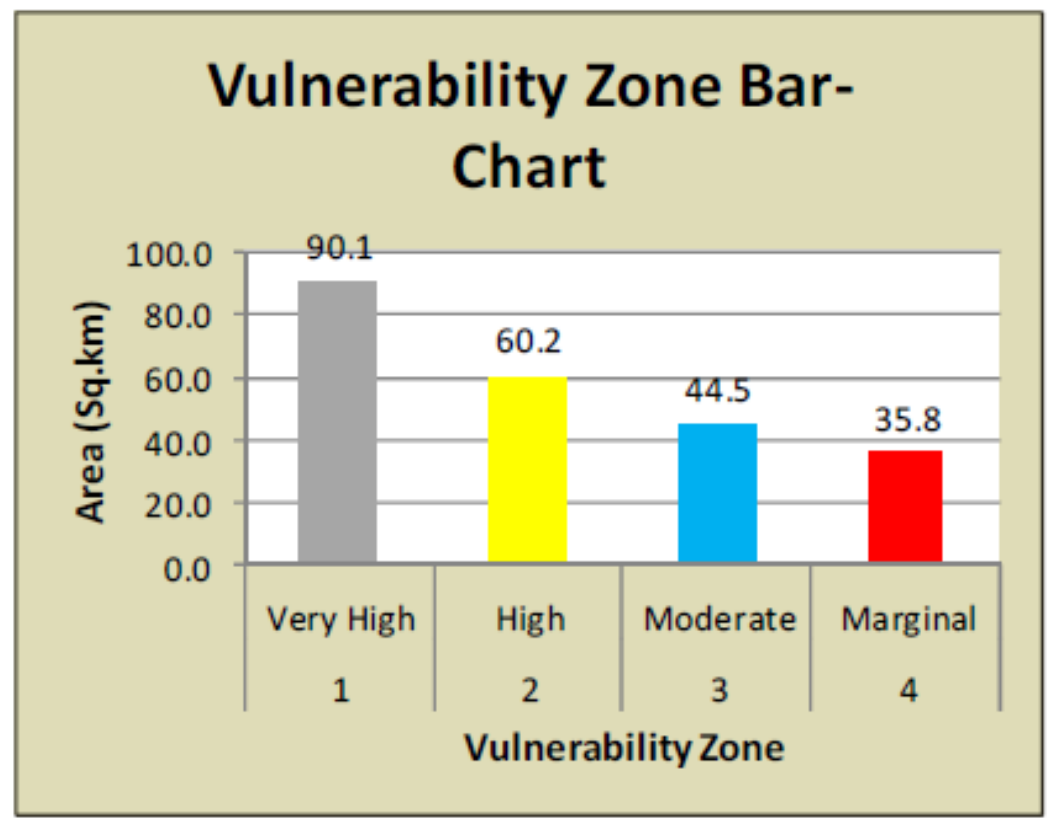

Fig. 7: Chart Showing the Degree of the Vulnerability Zone

Response analysis which has to do with the emergency response model was developed using the ArcMap Cost Distance Tool. The road network was used as the input source data while land cover (2015) of the area was used as the input cost distance surface data, and both input data were in raster format for this operation. The output was then re-classed and zoned into four response zones (very fast, fast, slow, and slowest) (Table 4), with respect to the travel route (road network) (Fig.8). These four response zones were assessed as regards the area (Sq.km) and percentage (\%) within the vulnerability zones (Fig.9).

Table 4: Response Zone Assessment

\begin{tabular}{llll}
\hline S/N & Zones & Sq.km & $\%$ \\
\hline 1 & Very Fast & 132.2 & 55.5 \\
2 & Fast & 59.5 & 25.0 \\
3 & Slow & 30.2 & 12.7 \\
4 & Slowest & 16.4 & 6.9 \\
& Total & 238.2 & 100.0 \\
\hline
\end{tabular}




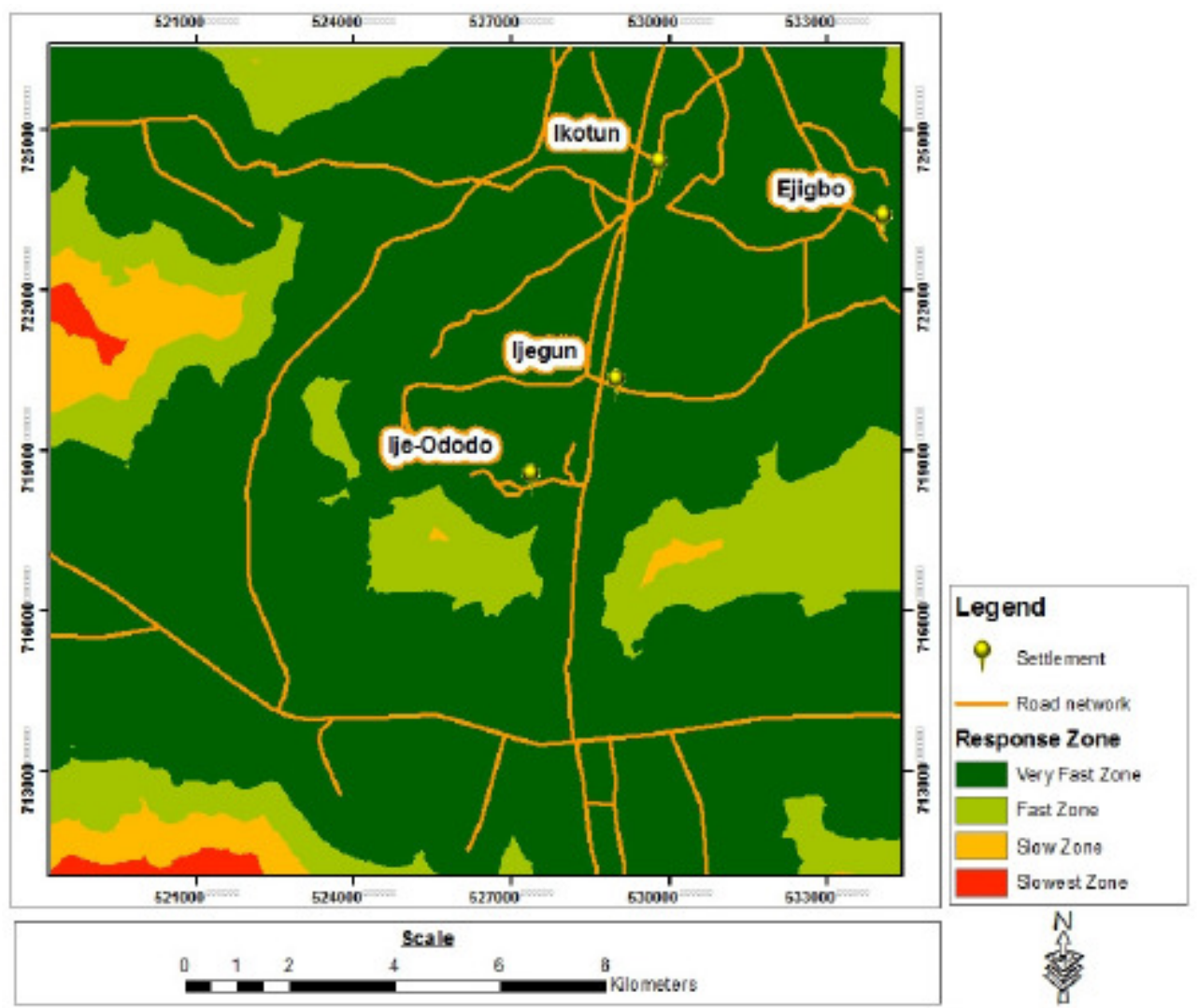

Fig. 8: Emergency Response Model Showing Response Zone

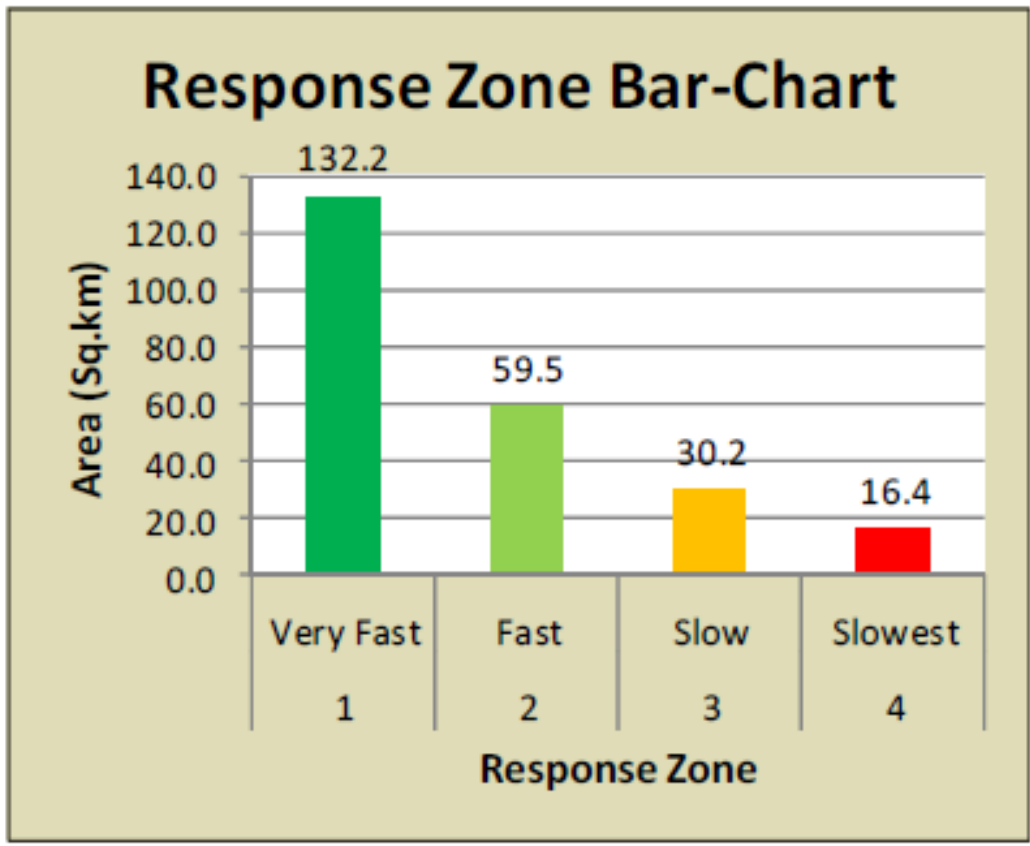

Fig. 9: Bar-chart showing Emergency Response Zone 


\section{Heavy Metal Test Analysis in Water and Soil Sample}

For heavy metals, standards are set to help check its permissible level for water and soil quality and it also envisage its Control when needed. "The Nigerian Standard for Drinking Water Quality" The Nigerian Industrial Standard (NIS) (2007) was used to compare this research analysis for water while, the Department of Petroleum Resources of Nigeria (DPR) (2002) was used for soil in accordance with Adaikpoh and Kaizer (2012). The water and soil sample test result for four heavy metals is presented in Table 5 and Table 6 respectively. Table 7 shows the results of the Control samples as against the Standard.

Table 5: Water Sample Metal Concentration (Ijeododo)

\begin{tabular}{llllll}
\hline & & \multicolumn{4}{c}{ Sample Concentration $(\mathrm{Mg} / \mathrm{L})$} \\
\cline { 3 - 6 } Heavy Metal & $\begin{array}{l}\text { Standard } \\
(\mathrm{Mg} / \mathrm{L})\end{array}$ & & \multicolumn{4}{c}{ Coordinates $(\mathrm{E}, \mathrm{N})$} \\
\cline { 3 - 6 } & & 528352,717017 & 528307,716866 & 528495,717858 & 528537,717982 \\
\cline { 3 - 6 } & 0.3 & Sample A & Sample B & Sample C & Sample D \\
\hline Iron $(\mathrm{Fe})$ & 0.01 & 0.040 & 1.810 & 2.610 & 0.050 \\
Lead $(\mathrm{Pb})$ & 3.0 & 2.012 & 0.020 & 0.030 & ND \\
Zinc $(\mathrm{Zn})$ & 153.190 & 35.510 & 1.820 & 1.732 \\
Phosphate $\left(\mathrm{PO}_{4}\right)$ & 5.0 & & & 69.840 & 289.370 \\
\hline
\end{tabular}

Table 6: Soil Sample Metal Concentration (Ijeododo)

\begin{tabular}{llllll}
\hline & & \multicolumn{4}{c}{ Sample Concentrations $(\mathrm{Mg} / \mathrm{Kg})$} \\
\cline { 3 - 6 } Heavy Metal & Standard & \multicolumn{4}{c}{ Coordinates (E, N) } \\
\cline { 3 - 6 } & $(\mathrm{Mg} / \mathrm{Kg})$ & 528352,717017 & 528307,716866 & 528495,717858 & 528537,717982 \\
& & Sample A & Sample B & Sample C & Sample D \\
Iron $(\mathrm{Fe})$ & 107 & 0.053 & 0.231 & 0.031 & 0.137 \\
Lead $(\mathrm{Pb})$ & 85 & 0.003 & 0.001 & 0.002 & 0.004 \\
Zinc $(\mathrm{Zn})$ & 146 & 1.732 & 1.631 & 1.690 & 1.723 \\
Phosphate $\left(\mathrm{PO}_{4}\right)$ & $0.001-1$ & 3.750 & 0.850 & 2.610 & 0.690 \\
\hline
\end{tabular}

Table 7: Water and Soil Control Sample Concentration (Ikotun)

\begin{tabular}{lllll}
\hline & \multicolumn{4}{c}{ Coordinates $(\mathrm{E}, \mathrm{N}): 529510,723403$} \\
\cline { 2 - 5 } Heavy Metal & Standard & Water $(\mathrm{Mg} / \mathrm{L})$ & Standard & Soil $(\mathrm{Mg} / \mathrm{Kg})$ \\
\hline Iron $(\mathrm{Fe})$ & 0.3 & ND & 107 & 0.021 \\
Lead $(\mathrm{Pb})$ & 0.01 & ND & 85 & 0.003 \\
Zinc $(\mathrm{Zn})$ & 3.0 & 0.035 & 146 & 0.431 \\
Phosphate $\left(\mathrm{PO}_{4}\right)$ & 5.0 & 0.010 & $0.001-1$ & 0.051 \\
\hline
\end{tabular}

\section{Discussion}

It is important to note that, this paper, determine the location of oil spill impacted areas, assess the impact of oil spill, used geospatial information analysis to evaluate the vulnerability of the affected settlements and develop a 
model for an emergence response plan for the study area.

The land cover distribution showed that the built up had the highest value of $58.9 \%$ compared to others, especially water body which was the lowest $4.8 \%$. And it is seen that, this trend of high built up area and low water body is same for the three land cover distribution year and this results affirms the fact that, a level of infrastructure development leading to land use had taken place in the study area due to high demand (both public and private interest); this is a common trend in Lagos State, Nigeria.Vegetation had similarly undergone some form of changes between the periods under study. In Table 1, vegetation land cover was higher in the first year (2011) and subsequently reduced. This reduction as seen in year 2014 and 2015 respectively was replaced by light forest. This reduction could be attributed to an increase in human activities (which of course includes oil theft and its attendant oil spill) in the study area. This was agrees with Okude and Ademiluyi (2006), and Omodanisi (2013).

For the Vulnerability analysis, vulnerability assesses how component in an environment would be at risk to the impact of source of hazard (Coburn et al., 1994) and that the degree of such is as a result of its exposure (Udoh and Ekanem, 2011). Table 3 showed that $15.5 \%$ of the area falls under the marginal vulnerability zone, $19.3 \%$ falls under the moderate vulnerability zone while $26.1 \%$ and 39.1 $\%$ of the area fall under the high and very high vulnerable zone respectively. The total vulnerability zone of the study was given as $100 \%$ and the degree spread represented in Fig.7. In developing the emergency response model, the response route was adopted to assess the response system, by the reason of the strategic placement of the vulnerable settlement for easy response and movement as the case may be. Closeness or the proximity of areas to good road network will certainly speed up the way and manner emergency responses are performed. This is against areas that are farther away where emergency responses will be slow. The response analysis (Table 4), the developed model (Fig. 8) and the degree of spread (in Sq.km and \%) (Fig. 9) representsthe response zones covered. From this findings, 16.4 Sq.km (6.9\%) of the area falls under the slowest response zone and 132.2 Sq.km (55.5\%) of the area fall under the very fast response zone. The purpose for this was to show that, for emergency purpose, areas close to the road will be easily accessible and siting of response centres will be best done along the road network, and within the settlements identified.

The results of the water and soil sample showed that iron, lead and phosphate were above the permissible limit as against zinc which was below for both sample A and sample B (Table 5 and Table 6). It took a shift, as only iron and phosphate were above and zinc below, showing that lead was a little above in a difference of $(0.02 \mathrm{mg} / \mathrm{l})$ for sample C, while for sample D only phosphate was above the Standard,and lead was not-detected. It can be deduced also that the concentration of iron, lead, zinc and phosphate in water and soil, were high with phosphate having the highest value when compared to the Control sample (Table 7) and the Standard. Owing to phosphate having the overall highest concentration; it brings to mind that high levels of phosphate is 
dangerous to man and animals and can cause several sickness and diseases that affect different parts of the body, especially the bone (Anderson, 1977).

Also agreeing with Adams et al. (2008) and Sonavane et al. (2009), the reason of soil contamination leading to the manifestation of heavy metals is basically due to oil spillage and the harmfulness to natural habitat and every living organism both great and small is evident (Onojake and Okonkwo, 2011, Babatunde and Tosin, 2012); hence the continuousin-take of heavy metal like Fe, by plant and vegetation in the soil are definitely possible, thereby resulting to a food chain hazardous crisis (Osuji et al., 2004).

\section{Conclusion}

This study identified the importance of Geospatial technique in handling oil spill incidence. Heavy metals dominance is of great concern to human and its environment. Wherefore, a strict monitoring of the oil pipeline will help guide against sabotage, and will reduce its grave impact. It is therefore paramount to take due diligence in tackling every issue, so as to build a better and moreconducive environment. There is therefore the need for a prompt response management plan-model (system) in Nigeria.

\section{Acknowledgement}

We are grateful to the Baale (The community leader) and the good people of Ijeododo community, for their warm welcome and hospitability during the course of the research and the Federal Ministry of Mineral Resource, Lagos State.

\section{Reference}

Adams, R.H., Guzmán, Osorio, F.J., Zavala Cruz, J. (2008). Water Repellency in Oil Contaminated Sandy and Clayey Soils. Int. J. Environ. Sci. Tech. 5(4): 445- 454.

Anderson, J.R., Hardy, E.E., Roach, J.T. and Witmer, R.E. (1976). A Land Use and Land Cover Classification System for Use with Remote Sensor Data. Geological Survey Professional Paper 964. A revision of the land use classification system as presented in U.S. Geological Survey Circular 671. First Printing 1976.Conversion to Digital 2001 (Optical Character Recognition).

Anderson, J.R., Hardy, E.E., Roach, J.T. and Witmer, R.E. (2001). A Land Use and Land Cover Classification System for Use with Remote Sensor Data. Geological Survey Professional Paper 964. A revision of the land use classification system as presented in U.S. Geological Survey Circular 671 of 1972.

Anderson, M.P. (1977). Long-term effect of low dietary calcium and phosphate ration on the skeletons of Zebus albifrons monkeys. J. Nutr., 107: 834-839.

Babatunde, S.B. and Tosin, A.O. (2012). Characteristics of Soils and Heavy Metal Content of Vegetation in Oil Spill Impacted Land in Nigeria. University of Agriculture, Abeokuta, and University of Agriculture, Abeokuta.

Coburn, A.W., Spence, R.J. and Pomonis, A. (1994). Vulnerability and Risk Assessment, Cambridge Architectural Research Limited, Cambridge, UK. 
Environmental Protection Agency (1999).Understanding Oil Spills and Oil Spill Response, www.epa.gov.oilsp/pdf.Accessed March 20, 2006.

Federal Ministry of Environment (FME) Abuja (2006). Nigerian Conservation Foundation Lagos, WWF UK and CEESP-IUCN Commission on Environmental, Economic, and Social Policy, May 31,(2006). Niger Delta Resource Damage Assessment and Restoration Project.

Hardy, E.E. and Anderson, J.R. (1973). "A Land Use Classification System for Use with Remote-Sensor Data".LARSSymposia.Paper 2. http://docs.lib.purdue.edu/lars_sym $\mathrm{p} / 2$.

Johnson, E. (2004). Nigerian Country Analysis Briefs. Nigeria Monthly Energy Chronology (2002-2004).

Lenntech Water Treatment and Air Purification (2004). Water Treatment, Published by Lenntech, Rotterdamseweg, Netherlands (www.excelwater.com/thp/filters/W ater-Purification.htm).

NDES (1997).Niger Delta Environmental Survey; Final Report, Phase I. Environmental Resources Managers Limited.

Ojediran, B. and Ndibe, J. (2005). Oil Spill Management. SPDC and the Environment. (2005).

Okude, A.S. and Ademiluyi, I.A. (2006). Implications of the Changing Pattern of Landcover of the Lagos Coastal Area of Nigeria.Department of Geography and Regional Planning, OlabisiOnabanjo University, P.M.B. 2002, AgoIwoye, Ogun State, Nigeria.
American-Eurasian Journal of Scientific Research, 1(1): 31-37, 2006 ISSN 1818-6785 (C) IDOSI Publications, 2006.

Omodanisi, E.O,Eludoyin, A.O., and Salami, A.T. (2013). A multiperspective view of the effects of a pipeline explosion in Nigeria. International Journal of Disaster Risk

Reduction http://dx.doi.org/10.1016/j.ijdrr.201 3.11.002i.

Onojake M.C. and Okonkwo, V.J. (2011). Trace Metals Associated with Oil Spillage: A case study. Department of Pure and Industrial Chemistry, University of Port Harcourt, Choba, Port Harcourt, Nigeria. J Chem. Pharm. Res., 3(6):742-751. (Available online: www.jocpr.com).

Osuji, L.C. (2002). Africa Journal of interdisciplinary study. 3 (1): 11-17. Cited by Onojake M.C. and Okonkwo, V. Trace Metals Associated with Oil Spillage: A case study. J. Chem. Pharm. Res., 2011, 3(6):742-751. Available online: www.jocpr.com".

Osuji, L.C. and Onojake, C.M. (2004). Trace Metals Associated with Crude Oil: A Case Study of Ebocha-8 Oil Spill-Polluted Site in Niger Delta, Nigeria, Chemistry and Biodiversity, 1: 1708-1715. http://dx.doi.org.10.1002/cbdv.2004 90129

Sekabira, K., OryemOriga, H., Basamba, T.A., Mutumba, G. and Kakudidi, E. (2010). Int. J. Environ. Sci. Tech., 7 (4), 759-770. Cited by EhiEromosele C.O, Okiei W.O. Heavy Metal Assessment of Ground, Surface and Tap Water Samples in 
Lagos Metropolis Using Anodic Stripping Voltammetry. Resources and Environment, 2(3): 82-86. Published online at http://journal.sapub.org/re

Sonavane, D.V., Lawande, S.P., Gaikawad, V.B. and Kuchekar, S.R. (2009). Seasonal Variation of Some Micronutrients in Soil Around Kurkumbh Industrial Area, Daund from Pune Districts, MS. Journal of Chemical and Pharmaceutical Research, 1(1): 282-285.

U.S. Environmental Protection Agency (USEPA) (2009). Measuring
Benefits of Oil Spill Prevention: Methods and Approaches. Office of Solid Waste and Emergency Response, Office of Emergency Management Regulation and Policy Development Division. April 29, 2009.

Udoh, J.C. and Ekanem, E.M. (2011). GIS based risk assessment of oil spill in the coastal areas of Akwalbom State, Nigeria. Department of Geography and Regional Planning, University of Uyo, Uyo, Akwalbom State, Nigeria 